\title{
Social Foundations of Regional Innovation and the Role of University Spin-offs: The Case of Canada's Technology Triangle
}

\author{
Harald Bathelt, Dieter F. Kogler \& Andrew K. Munro
}

\author{
Version Post-print/accepted manuscript \\ Citation Bathelt, H., Kogler, D. F., \& Munro, A. K. (2011). Social foundations of \\ (published version) regional innovation and the role of university spin-offs: The case of \\ Canada's Technology Triangle. Industry and Innovation, 18(5), 461-486.
}

Copyright / License

Publisher's Statement This is an Accepted Manuscript of an article published by Taylor \& Francis in Industry and Innovation on Jul 2011, available online: http://www.tandfonline.com/10.1080/13662716.2011.583462

Always cite the published version, so the author(s) will receive recognition through services that track citation counts, e.g. Scopus. If you need to cite the page number of the TSpace version (original manuscript or accepted manuscript) because you cannot access the published version, then cite the TSpace version in addition to the published version using the permanent URI (handle) found on the record page. 


\section{Social Foundations of Regional Innovation and the Role of University Spin-offs: The Case of Canada's Technology Triangle}

by

Harald Bathelt (corresponding author)

University of Toronto, Department of Political Science and Department of Geography, Sidney Smith Hall, 100 St. George Street, Toronto ON M5S 3G3, Canada, Telephone +1-416-946-0183, Fax +1-416-978-5566,

E-mail: harald.bathelt@utoronto.ca, URL: http://www.harald-bathelt.com

\section{Dieter F. Kogler}

University College Dublin, School of Geography, Planning and Environmental Policy, Newman Building, Belfield, Dublin 4, Ireland,

E-mail: dieter.kogler@ucd.ie

\section{Andrew K. Munro}

University of Toronto, Institute for the History and Philosophy of Science and Technology, Victoria College, 91 Charles Street West, Toronto ON M5S 1K7, E-mail: andrew.munro@utoronto.ca

Paper re-submitted to Industry and Innovation 


\title{
Social Foundations of Regional Innovation and the Role of University Spin-offs: The Case of Canada's Technology Triangle
}

\begin{abstract}
The goal of this paper is to explore the social foundations of regional innovation by analyzing the role of universities in promoting technology transfer and the creation of innovation networks. The argument put forward is that regional innovation benefits from, and is stimulated by, horizontal and vertical knowledge flows and trans-regional networks, enabling firms to benefit from wider knowledge transfers between old and new establishments, large and small operations, and within and across sectors. The empirical study focuses on the Kitchener and Guelph metropolitan areas, referred to as Canada's Technology Triangle (CTT), where a larger number of firms related to information technology (IT) have been successfully launched since the 1970s in the area surrounding the University of Waterloo. This research investigates to which degree these university spin-offs and start-ups have established regional networks in innovation, their level of dependence on global knowledge networks, and whether this dynamic has produced spillovers to other regional industries.
\end{abstract}

Keywords: Regional innovation, Regional networks, University spin-offs, Technology transfer, Canada's Technology Triangle (CTT)

JEL Classifications: D83, L24, L26, M13, O31 


\section{Introduction: Regional Innovation and the Case of the CTT Region}

It has become widely acknowledged that knowledge and innovation are key resources of economic success (Lundvall and Johnson, 1994), and that learning is the decisive process that stimulates knowledge creation and innovation (Lundvall, 1988; Malecki, 1991). Further, regional well-being depends on the capacity to stimulate processes of interactive learning, networking, and innovation at the local level (Cooke and Morgan, 1998; Gertler, 2004). In this context, this paper investigates the potential contribution of university spin-offs and start-ups to the development of technology clusters. As pointed out in the literature, such firms can stimulate regional economic growth and competitiveness (Etzkowitz et al., 2000; Vohora et al., 2004). The seminal works of Roberts (1968), who examined technology-oriented spin-offs from MIT along Boston's Route 128, and Cooper (1971), who studied similar spin-off phenomena in Silicon Valley, are especially notable in this regard. While Route 128 and Silicon Valley have established themselves as the prototypes of advanced high-technology/IT regions (Saxenian, 1985; de Jong, 1987), relatively few other examples exist of regions that might have benefited from equally strong local university spin-off activities and related innovation processes.

The Kitchener and Guelph metropolitan areas, about $100 \mathrm{~km}$ west of Toronto, around which the initiative "Canada's Technology Triangle" (CTT) was founded in the late 1980s (Cities of Cambridge, Guelph, Kitchener, and Waterloo, 1988; Chevreau, 1988), is an example where such processes have been assumed to have taken place. ${ }^{1}$ The region has received a lot of attention by policy makers

${ }^{1}$ CTT was jointly established by the cities of Cambridge, Guelph, Kitchener, and Waterloo to market the region's technological strengths and reduce inter-municipal competition (Bathelt and Hecht, 1990). Although Guelph left this initiative later to market its strengths individually, the local economies are still linked to one another, draw from a shared 
because it has shifted its economic focus from traditional industries to new IT-related businesses. In recent years, the regional economy achieved above-average performance levels, according to indicators such as job growth, unemployment rate, or average household income, as indicated in Table 1. Between 2001 and 2006, the CTT region experienced an increase in population and jobs that was significantly higher than the national and provincial growth rates, and similar to those found in the Toronto CMA.

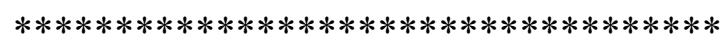

Insert Table 1 about here

Related to this, a myth of dynamic technology growth surrounding the spin-off activities of the University of Waterloo has been created and actively promoted by regional business organizations, such as Communitech and CTT Inc. ${ }^{2}$ Upon closer investigation, our understanding behind the successes in economic development and regional innovation still appears limited. The region does not form a true regional industry cluster of closely interrelated firms of a particular value chain (Bathelt, 1991). What we find instead is a highly heterogeneous and segmented regional economy with businesses that are characterized by limited commonalities. The region hosts a variety of larger and smaller establishments, old and young firms, and businesses with diverse manufacturing and service

labor market, and depend on similar economic conditions. Therefore, the entire region was of interest in this study, and will be referred to as CTT.

${ }^{2}$ Communitech is an industry-led organization that was started up by 40 founding companies in 1997 with the goal of supporting the region's technology basis. Currently, the organization has more than 450 members including large and small firms, as well as public entities (see http://www.communitech.ca, date accessed April 13, 2009). CTT Inc. is a notfor-profit, private-public economic development organization whose mandate it is to market the region to the world (see http://www.techtriangle.com, date accessed August 10, 2010). 
backgrounds. There is no simple explanation for the overall success of these different economic segments.

In this context, the goal of this paper is to provide clarity regarding the relationship between university spin-off activities, knowledge networks, and innovation in the CTT region. Our goal is to provide a better understanding of the social foundations - in the sense of inter-firm linkages - of regional innovation and the processes that drive knowledge creation by analyzing, first, the vertical and horizontal networks underlying innovation and, second, the institutional support for such activities. The IT sector was chosen for this research, as spin-offs/start-ups in this industry have the greatest potential - compared to other regional ventures- to become integral parts of the wider production and research networks in the CTT region, possibly developing linkages within and across sectors.

This paper is structured as follows: In section 2, we present our conceptual framework, which revolves around the role of innovation and university spin-off firms in regional clusters. Section 3 summarizes former research in the CTT region, specifically with regards to economic development and restructuring, and section 4 discusses the research approach and methodology applied. In section 5, we examine the local and non-local social relationships in the CTT region as they relate to innovation, and investigate the role of institutional support. Section 6 summarizes the main findings and draws conclusions regarding the effects of IT-related university-related spin-offs on regional innovation.

\section{Innovation and University Spin-offs in Regional Clusters}

\subsection{Social Foundations of Innovation and Cluster Theory}

In this section, we outline the conceptual framework used in this study by focusing on the conditions for regional clustering and innovation. As the region under investigation cannot be described as a fully developed industry cluster, we focus on the nature of linkages and knowledge 
flows that could support cluster formation and innovation in the future, especially on the role of university spin-offs and their relationships with established firms.

In the knowledge-based economy, creating and sharing knowledge has become key to generating economic growth and competitiveness (Lundvall and Johnson, 1994). Much of the literature on regional innovation and clustering has pointed out that firms that establish linkages to other firms in the same or a similar value chain within a region, have enhanced opportunities for interactive learning (Cooke and Morgan, 1998; Morgan, 2004), which will stimulate innovation processes (Lundvall, 1988). Based on observations concerning the tendency for firms in complementary industries - defined by value-chain-related linkages - to form agglomerations (Porter, 1990; 2000), cluster theory has developed as a network approach that examines material linkages and knowledge flows between these firms (Pinch et al., 2003; Visser and Atzema, 2008). In such settings, the co-location of firms provides numerous opportunities for inter-firm linkages (Storper and Walker, 1989; Gordon and McCann, 2000; Preissl and Solimene, 2003). They offer the potential for frequent face-to-face communication, which enhances opportunities for firms to resolve conflicts and exchange complex information more easily. Close geographic proximity, however, does not automatically ensure that firms engage in such exchange (Amin and Cohendet, 1999); it can operate as a catalyst for channeling different corporate knowledge bases and organizational cultures, thereby increasing the potential to develop common understandings and interpretative schemes (Bathelt et al., 2004).

Clusters can be distinguished on several key dimensions (Spencer et al., 2010): The vertical dimension typically consists of specialized suppliers and service providers that generate a division of labor, allowing each firm to focus on their core area of expertise (Malmberg and Maskell, 2002). This reduces transaction costs and provides incentives for new firms to locate in the cluster, thus stimulating the development of a specialized labor market (Scott, 2006). The horizontal dimension of a cluster consists of the firms that compete with each other in the same or related market segments, possibly establishing a precondition for vertical growth (Porter, 1990; Maskell and Lorenzen, 2004). These 
firms may not collaborate in joint research projects, but they have opportunities to closely monitor their rivals who develop similar products under similar conditions. This increases opportunities for mimicry and signals the need to differentiate products.

Other organizations are also connected to clusters and can provide significant input to the firms, such as universities, government agencies, standards councils, and trade agencies (Bathelt et al., 2004). Following Setterfield (1993), they establish the formal basis for institutions, in the sense of correlated behavior of agents. The institutional dimension frames economic interaction in the cluster, allowing specialized users and producers to discuss and solve particular problems, and develop reasonable expectations regarding each other's actions (Hodgson, 1988; MacKinnon et al., 2009). While we have already emphasized that the CTT economy cannot be conceptualized as a coherent industry cluster, extended practices of vertical and/or horizontal cooperation and knowledge exchange are nonetheless important for further agglomeration and economic growth.

In the context of our study, the question arises as to what potential exists in the CTT region to strengthen cluster-like developments and overcome the negative effects of the global economic crisis. Concepts surrounding new cluster formation often emphasize the emergence of "lead" or "anchor" firms (see, for instance, Wolfe and Gertler, 2004; Henn, 2006). Whether these are established firms that decide to enter into a new industry, spin-offs from existing firms, or start-ups from university laboratories (Storper and Walker, 1989), a key function of these firms is that they initiate something different than what was being done before in the cluster. When industries are new, the number of regional firms moving into this industry may rise quickly, leading to a high rate of innovation, new firm formation, and firms attempting to fill market niches (Klepper, 1996). Once lead firms develop within a dynamic regional context, entrepreneurialism and firm foundation may become important mechanisms for further agglomeration (Feldman and Francis, 2004).

In emerging high-technology industries, knowledge is more likely to be embodied in human capital rather than physical capital, through which knowledge is more easily transferred via the 
founders to new firms (Klepper and Sleeper, 2005). Employee spin-offs replicate and reproduce at least some of the routines of the parent firms. Employees of incumbent firms usually leave their parent organizations with detailed knowledge of technologies and the respective marketplace, allowing them to potentially fill the horizontal and vertical dimensions of the cluster by moving to market segments that the parent firms were unable to meet (Feldman and Francis, 2004). While employee spin-offs may slowly thicken a growing agglomeration, university-based start-ups have the potential for more radical shifts in innovation and organizational structures.

\subsection{University Spin-offs and Innovation Networks}

New ventures are typically viewed as university spin-offs if they result from a process of commercializing academic research efforts, but, beyond this understanding, significant variations exist in the definition of such ventures (Pirnay et al., 2003; Lockett et al., 2003; Bathelt et al., 2010). The present study takes this as a starting point, and - similar to the categorization of university spin-outs developed by Nicolaou and Birley (2003) - considers a multitude of aspects in the definition of such ventures, including the origin of the firm's core technology, the current or former affiliation of the founding members, and the source of funding used to start up the firm, all of which have to have some link to a university. For the most part, university spin-offs face similar obstacles when they are initially launched as conventional high-technology start-ups, but two significant differences exist (Vohora et al., 2004): First, university spin-off firms originate from a non-commercial environment, which sometimes lacks the proper resources that are available to spin-offs from other businesses in the

private sector. Second, corporate spin-offs are frequently able to achieve legitimacy and accountability in the context of the parent organizations and their reputation in the market place (Hannan and Freeman, 1993), while university spin-offs lack such advantages. 
University spin-off and start-up ventures are widely acknowledged as an efficient technology transfer mechanism for supporting regional economic competitiveness (Etzkowitz et al., 2000; Wright et al. 2004). Studies of regional economies show that the successes of start-up firms and their potential to grow into lead firms depend on different configurations (Hayter 1997), two of which deserve particular attention:

First, we know from empirical investigations that broad regional effects are more likely to occur if the regional economy draws from technological complementarities and related overlapping knowledge bases that enable firms to establish vertical regional networks and engage in knowledge exchange (Boschma, 2005). A corresponding regional ensemble of firms can take the form of a regional thickening of a particular value chain or of a fully-fledged industry cluster with a welldeveloped supplier and institutional infrastructure (Porter, 1990; Malmberg and Maskell, 2002). In the case of a cluster, regional networks can develop and dynamic local knowledge flows, or buzz, can unfold (Storper and Venables, 2004; Bathelt et al., 2004). In contrast, if local firms are not closely related to one another in terms of their utilized technology and knowledge base, possibilities for local networking and related growth triggers likely remain limited (Nooteboom, 2000). Instead, we might observe that growth has few collective qualities but is a result of individual firm successes that rely on bonds with partners outside the regional or even national economy.

Second, strong connections to global value chains and access to external markets and technology partners are key in generating growth impulses, and support processes of innovation in the regional context (Oinas and Malecki, 1999; Owen-Smith and Powell, 2004; Bathelt et al., 2004).

Ideally, both configurations jointly enable university spin-offs to provide ideas and incentives for renewal and reorganization in established firms (Hannan and Freeman, 1993). Through this, negative consequences of structural crises in a region could be overcome, as suggested by the model of regional re-bundling (Bathelt and Boggs, 2003). Feldman et al. (2005) describe a similar sequence in the case of the biotechnology industry as a process that can lead to the establishment of new clusters. On the 
contrary, if external market or technology linkages are weak or non-existent, regional growth likely remains limited, and the danger of negative technological lock-in may increase, resulting in an unstable regional economy.

If the conditions for neither of the two configurations are in place, strong regional economic growth will be an unlikely outcome. University spin-offs that initially appear promising would remain small or disappear from the market. From this, the goal of the following analysis can be rephrased to investigate whether successful innovation in the CTT region's IT sector is related to the first configuration, i.e. strong regional networking or cluster-like linkages; or whether it is mainly related to the second configurations, i.e. individually successful, globally-integrated IT firms; or whether a combination of both applies. As such, we will analyze the local and trans-local linkage patterns in innovation, and the structure of institutional support. Before proceeding with this analysis, the next section discusses the historical background of spin-off and growth processes in the CTT region.

\section{Previous Research on Growth and Spin-off Processes in the CTT Region}

The CTT region was traditionally, and still is, characterized by a diversified manufacturing base. In the post-World War II period, manufacturing growth was driven by such industries as fabricated metals, machinery, and electrical products (Wahl, 2007; Bramwell et al., 2008). The region also developed a strong basis in the automobile supplier/transportation equipment sector (Rutherford and Holmes, 2008). Since the 1970s, this region experienced the impetus of spin-off processes from university research. Specifically surrounding the activities of the University of Waterloo, numerous firms in the area of information technology (IT), such as Dalsa, Open Text, Research in Motion (RIM), Sybase, or Waterloo Maple, were successfully launched, altogether establishing a growing regional technology basis (Bathelt and Hecht, 1990; Parker, 2001; Colapinto, 2007; Bramwell et al., 2008). 
This process was related to the foundation of the University of Waterloo in 1959 as a university with an engineering focus, allowing members to own patents from university research. Industrial leaders, such as Ira Needles from BF Goodrich, played an important role in the design of the university. They shaped the university's co-operative education program and its openness toward private sector collaboration and funding (Bathelt, 1991; Wahl, 2007; Bramwell and Wolfe, 2008). Compared to other Canadian universities, the University of Waterloo not only had a more pronounced focus on establishing university-industry linkages, but also developed a stronger focus on basic and applied research, focusing on technologies of potential economic value. According to Niosi (2000), the University of Waterloo was Canada's largest research university in the late 1960s, representing a significant driver of a more research-oriented, as opposed to a resource-led, national production and innovation system. Until 2007, the University of Waterloo was incubator to 47 spin-off firms, which were derived, in a narrow sense, from university research, 24 of which were directly related to IT industries. ${ }^{3}$ The university's initial advantage, however, decreased over time. By the 1990 s, observers already began speculating that the overall key to economic growth and success in the region was primarily due to the university's co-op program and a constant flow of highly qualified graduates, who found a job in the region's growing technology sector, rather than a consequence of university spin-off processes (Bathelt, 1991). ${ }^{4,5}$

\footnotetext{
${ }^{3}$ There were also other educational organizations that spurred firm formation in the region. The University of Guelph, for instance, produced at least 13 spin-off firms outside the IT sector, and organizations, such as Conestoga Community College, which claims that more than 200 enterprises were started by its graduates (Conestoga College, 2003), also led to technology-based start-ups.

${ }^{4}$ According to a study in 1988, most university spin-offs were still relatively small with about $60 \%$ having 10 employees or less; the 39 firms which were interviewed at that time had created a total of 545 jobs (14 jobs per firm), most of which were located in the region (Bathelt, 1991). About $20 \%$ of the university spin-offs had had little business success, and did not survive beyond 1988 .
} 
Aside from start-ups surrounding the University of Waterloo, the region also attracted a number of multinational IT firms such as Google, Hewlett-Packard, Microsoft, and NCR, which established branches or acquired existing technology firms. Although $87 \%$ of the firms surveyed in information and communication technologies in a Communitech (2006) report had in-house R\&D, most of this focused on incremental development tasks rather than basic or applied research. In addition, local technology firms had seemingly not developed extensive input-output linkages in the regional economy (Xu, 2003; Bramwell et al., 2008).

Overall, the regional economy successfully transformed its economic base, while remaining strongly diversified. As shown in Table 2, traditional manufacturing sectors such as textile mills, clothing, and leather manufacturing lost 50-60\% of their employees in the Kitchener CMA between 2001 and 2006. This structural change was over-compensated by a $20 \%$ increase of employment in plastics/rubber products and computer/electronic product manufacturing. Most knowledge-based and producer-related services also experienced substantial job growth (see, also, Table 1). In the areas of professional, scientific, technical, and educational services, total employment increased from about 40,000 to 47,500 between 2001 and 2006.

As will be argued below, this did not, however, lead to the establishment of a well-developed industry cluster with closely-knit producer-user networks.

Insert Table 2 about here

${ }^{5}$ Lazaridis, one of the co-founders of RIM, repeatedly pointed out that the flow of new graduates would be the most important source of technology transfer from the local universities to RIM (Brady, 2004; Livingston, 2007). 


\section{Research Approach and Methodology}

In order to explore the social foundations of regional innovation, as part of a larger study concerning the social dynamics of economic performance in Canadian city-regions (Holbrook and Wolfe, 2005), we conducted a largely qualitative study of IT-related university spin-offs/start-ups, using semi-structured interviews to understand the economic processes and decisions that led to the present structure of knowledge flows and producer-user linkages in the CTT region. At the same time, we aimed to carefully draw a sample of firms that would allow us to distinguish between more and less important trends.

The total population of start-ups and spin-offs considered was composed as follows: As a basis for our research, we used a list of 47 spin-off firms from the University of Waterloo (provided by the University's Intellectual Property Management Group in August 2007) and 14 firms where the University of Guelph played an active role in the start-up process (provided by the University's Business Development Office in September 2007). Further, we had a list of 227 start-up firms, established by PricewaterhouseCoopers (2001a), from a region-wide industry survey in which firms identified themselves as being related to the regional universities, on a scale from strongly related ("but-for") to weakly related ("at least in part") (PricewaterhouseCoopers, 2001b). ${ }^{6}$ We viewed the firms indicated by the universities as true spin-off firms since they were closely related to university research. The other firms identified by PricewaterhouseCoopers (2001a) were viewed as universityrelated start-ups. ${ }^{7}$

$* * * * * * * * * * * * * * * * * * * * * * * * * * * * * * * * * * *$

${ }^{6}$ The PricewaterhouseCoopers list is not unproblematic as we cannot strongly comment on its reliability. It is also somewhat dated, but was the only list of this type available. As such, it was key to our research.

${ }^{7}$ For a comprehensive typology of university-related start-up and spin-off firms, see Bathelt et al. (2010). 
Insert Table 3 about here

As shown in Table 3, the lists included 119 IT firms, 83 firms in engineering and engineering consulting, and 86 firms from a variety of fields, including architects, specialty equipment outlets, and even a dance studio and a flower shop. We decided to focus only on the IT population because these firms had the largest innovation potential and potential to form regional producer-user networks, possibly even across different value chains. Before beginning our sampling process, we researched each of the 119 IT firms on the list and collected information, such as business focus, location, firm size, and a potential interview partner. ${ }^{8}$

Out of this population, 16 firms (13\%) were not found, and another $36(30 \%)$ were not located in the region and were thereby excluded. An additional 8 firms (7\%) were acquired by other IT firms on the list, whereas another 17 establishments (14\%) were confirmed closed. After this process, we arrived at a population total of 42 IT firms relevant for our study (Table 3). At the end, we contacted 32 out of these 42 firms (76\%). Of these, 14 were unresponsive or did not agree to give an interview. ${ }^{9}$ Although this is a seemingly small sample of firms, we should keep in mind that these firms represent a substantive portion of the extant regional IT-based start-up/spin-off firms, particularly related to the University of Waterloo, and belong to the most innovative segment of start-up/spin-off firms in the

${ }^{8}$ This was a time-consuming process, which included checking the virtual firm directories of the region and the cities' business development offices. See http:/www.techtriangle.com/search/business.cfm, as well as several other websites (i.e. Canada411, Waterloo Tech Digest, uwRyan.com, Strategis - Government of Canada), and Google.

${ }^{9}$ This relatively high rejection rate of $45 \%$ might also be an indication that the region has been over-studied in recent years, resulting in many interview requests for local firms. 
region. ${ }^{10}$ Compared to the relevant firm population of 42 firms, a substantial proportion (43\%) was interviewed (Table 3). These interviews were augmented with an additional 7 interviews with regional experts, such as university technology transfer personnel and economic development officials. The interviews conducted took between 45 and 75 minutes on average, and were mostly held on a face-toface basis. Altogether, we are thus confident that our sample allows us to draw careful conclusions regarding the impact of IT-related university spin-offs/start-ups in the region, and their innovation linkages.

During our interviews, we investigated the way in which spin-off/start-up firms established regional producer-user networks, in which way they developed global linkages, or pipelines, and whether this dynamic produced spillovers to other regional industries, due to practices such as intersectoral networking, technology transfer, and job hopping. We primarily talked to the founders, executives, or research heads of the firms. Our questions focused on three main areas of interest: First, we asked with what goals and incentives, and under which conditions, the firms were started up in the region. The second set of questions was concerned with material linkages and knowledge flows related to innovation, within the region or with partners in other regions and countries. Third, we were interested in finding out whether local institutional support and economic policies provided incentives to develop local linkages, and whether this led to cross-industry effects in innovation. Key characteristics of the firms interviewed are shown in Table 4; the results of the interviews are discussed in the next section.

${ }^{10}$ Many of the IT-related spin-offs/start-ups are software firms, or have a strong software component. They belong to different value chains and, thus, do not form a cluster-like structure. They are also not involved in an extended social division of labor, especially with respect to upstream linkages (compare Trippl et al., 2009). It should be emphasized, however, that many of the spin-offs/start-ups in CTT also have a hardware segment, or grew out of such a segment. 


\section{Local and Non-local Social Relations in Innovation in the CTT Region}

The transformation that has taken place in the CTT region from an economy based on traditional manufacturing to one with a substantial proportion of IT-related businesses is often attributed to knowledge transfers and growth triggers based on university spin-off processes and related network effects. This suggests that the regional firms are linked through cluster-like relations or other forms of durable inter-firm linkages, as described in the conceptual part (Lundvall, 1988; Gertler, 2004). In contrast, our research shows that local firms are not closely related to one another and to other regional firms in their technological and knowledge base, thus limiting the possibilities for local innovation networks. As discussed below, firms tend to engage in international linkages to provide necessary growth impulses.

\subsection{Producer-User Linkages and Knowledge Flows}

To acquire information about the regional impact of university-related spin-offs/start-ups, we asked our sample firms to describe the nature of producer-user linkages and other important knowledge flows, and what impact these relationships had on their innovation processes, to investigate the qualities of the vertical dimension of the cluster (Malmberg and Maskell, 2002). In addition to intra-regional linkages, we inquired about knowledge pipelines that exist into, or from, other regions, as described by Bathelt et al. (2004). The results are presented according to supplier, customer, Internet, community/labor market, and corporate linkages, and their spatiality:

(i) Supplier linkages. In terms of supply-side relations, firms generally responded that reliable suppliers are important, but not critical to their innovation process: Approximately two-thirds (9 firms) 
viewed them as relatively unimportant, and only 2 as important (Table 5). Similarly, the existence of local suppliers was rated as being unimportant in all cases. Nearly all firms (15) indicated that the percentage of supplies acquired locally was $10 \%$ or less (Table 4). Key supplies were typically not drawn from within the region. Many firms recognized suppliers more broadly as development partners, but not as key figures in the generation of new ideas for innovation. As one interviewee pointed out, "[o]ur suppliers provide us with tools ... the capabilities of those tools can be important, but as far as applying new ideas, practically zero" (Interview 8). This is also confirmed by the findings of Rutherford (1996) and Bramwell et al. (2008). It should be emphasized, however, that software developers do not draw heavily from suppliers, but rather purchase pre-packaged and standardized software applications universally available. In this respect, material supplier linkages might not be the best indicator to judge the local innovative practices of these firms (Trippl et al., 2009). ${ }^{11}$

The three firms which indicated that suppliers played a significant role in the development of new ideas and product innovations were hardware producers. One was purchased by a multinational firm with numerous R\&D facilities located around the world. The interviewee indicated that, before the firm was acquired and still had local ownership, "[v]endors were more frequently located here. Now that we're an R\&D site, we're linked more with other global players" (Interview 1). The director of another firm that was also acquired by a multinational server and database company commented on supplier relationships saying that "[t]hese are negotiated by our head office in the US. I have no input into these contracts" (Interview 4). In both cases, as the management of these firms moved out of the region, a shift occurred away from local to global supply sources, mediated through their respective corporate networks. This does not imply that the supplier relationships, which would have otherwise

${ }^{11}$ An early study indicated that regional input linkages in CTT were not necessarily much weaker though than in other North American IT regions (Bathelt, 1991). 
existed with local vendors, would have been significant inputs for innovation; the absence of opportunities, however, makes it unlikely that regional supplier-producer relationships, as described by Porter (2000), will be built in the near future.

(ii) Customer linkages. In comparison to suppliers, the role customers play in the innovation process was considered far more crucial by our interviewees: Two-thirds of respondents (12 firms) indicated that customers were important or critical for innovation (Table 5) - similar to what would be expected according to the network literature (Lundvall, 1988). When asked where the ideas for new products or services came from, each firm cited customers as one of the key sources for the generation of new ideas. All respondents rated customers as either very important or critical to their innovation processes. There was no sectoral difference observed here between software and other IT firms. The customer linkages are generally more robust from an innovative perspective; yet, we again did not find appreciable customer relationships within the region - different from expectations raised in the cluster literature (Malmberg and Maskell, 2002; Gertler, 2004) - confirming a weak vertical dimension.

The location of customers, similar to suppliers, was deemed not to be relevant by the firms that were interviewed. Nevertheless, it should be noted that this is likely a standard answer to questions concerning the role of proximity, which does not necessarily reflect the actual nature of social relations. The likelihood that close-by customers receive more attention in terms of regular interaction practices than distant customers is certainly higher, especially if we consider the significant role face-to-face interaction plays in this context (Gertler, 2004; Storper and Venables, 2004).

One firm in our sample, a software company making online customer service inquiry and database software, described in detail how a branch office was established: The founders of the firm hired an executive and located much of the sales division of the company to Toronto to leverage the executive's contacts in the financial services sector to expand into a new market segment. Although this case does not allow conclusive statements, examples such as Dalsa's establishment of a small office in Hollywood, Open Text's acquisitions in other countries, and RIM's international expansion, 
which have been publicized through the media, indicate that firms were aware of the need to be present in other markets to acquire important information and develop tighter customer relationships.

All of the firms answered that having local customers was not critical to their innovation process, while three quarters (14) also emphasized that they sell to a global client base (see, also, Bramwell et al., 2008). ${ }^{12}$ The CTT region and other southern Ontario markets were not significant to these firms in terms of the percentage of their overall sales: Many firms (14) that provided detailed data indicated that their regional sales were $5 \%$ or less (Table 4 ). It should be noted that most firms, particularly in software, had ongoing support contracts with their customers, and thus received regular feedback from them. The president of a small software firm that provides logistics management software explained that one of his major clients was located in Cambridge in the CTT region, and a second one in the U.S., in the state of Mississippi. He experienced no difference in his ability to service the two customers. The primary methods of communication between these firms were the telephone and the Internet, and he spent relatively little time at either of the clients' sites. This is an example that indicates that customers that are close-by, who are rare in our study to begin with, do not automatically experience preferential treatment - different from general assumptions in the network literature (Lundvall, 1988).

(iii) Internet linkages. Although customers were a major source of new ideas, our interviews suggested that firms who went about implementing these ideas often stumbled over technological hurdles. In aiming to solve these problems, they mentioned the need to turn to the Internet and its user communities to find solutions. As a consequence of these practices, they no longer required close connections with suppliers, customers, or peer-firms. As one interviewee powerfully stated, "[o]ne of the best skills you can have is finding things on the Internet ... Ten years ago, I could do my work

\footnotetext{
12 This finding of lower than expected regional customer linkages is also confirmed in a study of the Vienna software sector (Trippl et al., 2009).
} 
without the Internet, now I can't. We're dependent on the Internet for this sort of help" (Interview 2). This included the use of virtual user and expert communities which provide assistance with, and solutions for, specific technical problems (Jeppesen and Frederiksen, 2006), potentially leading to incremental improvements. ${ }^{13}$ In our sample, two thirds of the firms rated the Internet as an important source for finding solutions to problems. In addition, one third of the firms mentioned intra-firm problem-solving as a decisive instrument in this regard (Table 6), suggesting again that extended interfirm linkages or networks do not exist in the region.

(iv) Community/labor market linkages. Although we assume that the local community of IT firms created a considerable pool of specialized labor, which would enable ongoing exchange and problem solving, this was only occasionally pointed out in the interviews. One respondent stated: "I know where to go and who to ask [in the local community] if I have a technical problem." However, more frequent possibilities for such knowledge exchange seemed limited because of different specializations of the firms and the lack of a cluster context. Whenever more generic knowledge was discussed, possibilities for local interaction seemed stronger. While several of our interviewees talked positively about the local labor market and mentioned that a "critical mass" had accumulated in the region over time, they also pointed to increasing shortages and greater challenges in finding the "right people", brought on by enhanced competition for the existing labor pool in the region. The agglomeration of IT firms apparently induces regular face-to-face interaction and accidental encounters with colleagues or neighbors, but relatively little of the expected buzz dynamics emphasized by Storper and Venables (2004) were reported during our research. German social clubs (common in the Kitchener-Waterloo region due to its heritage), neighborhood events, and the advantages of living in a smaller urban fabric were repeatedly mentioned as vital elements that make up the character of the

\footnotetext{
${ }^{13}$ Such practices might, however, not be conducive to discontinuous innovation.
} 
local community. We believe that these social events may also play a role for the regional community of IT firms, yet the results of our research do not allow us to say that they have a notable impact on innovation.

(v) Corporate linkages. Our research regarding the genealogy of start-up and spin-off firms also provided extensive evidence of organizational changes as many firms became involved in acquisitions and mergers (Table 3). ${ }^{14}$ If acquired by foreign firms, they either stayed in the region as more or less independent subsidiaries, or were closed down after a few years and left. ${ }^{15}$ As a corollary of these changes, we assume that local producer-user linkages have also shifted (see Xu, 2003). Even if local linkages might have played a somewhat stronger role originally, several interviewees indicated that corporate networks and non-local business relations became much stronger over time. This can be viewed as a logical move to gain access to a broader corporate competence base and larger markets. We suspect that direct customer contact was still significant for these operations in acquiring strategic information about product performance and the future direction of innovation. ${ }^{16}$

Aside from the increasing role of Internet user communities (Jeppesen and Frederiksen, 2006), a possible explanation for the above described results might be related to the nature of these firms that are highly specialized with few local customers or suppliers. Consequently, the firms did not benefit from local buzz - a tendency also observed by Trippl et al. (2009). Instead, they operated much like

\footnotetext{
${ }^{14}$ We could not find a particular pattern to explain why these firms were acquired, but anecdotal evidence suggests that firms acquired local firms to gain a foothold in the region to access firm-specific knowledge and gain priority access to graduates.

${ }^{15}$ Rarely, however, did it seem that the founders themselves left the region in these cases. In fact, there were a few instances where the founders later started a new regional business in a different technology segment.

${ }^{16}$ This also confirms the findings of other studies which find life-cycle shifts in cluster development, leading to weaker local material and institutional linkages over time (e.g. Niosi and Banik, 2005; Rutherford and Holmes, 2007).
} 
"stand-alone" firms in the regional economy. Some were also too small in terms of resources and employees to establish frequent and intensive face-to-face contacts with distant customers - and thus did not develop the buzz-and-pipeline structure described by Bathelt et al. (2004). Given the degree of specialization, it appears plausible that the reliance on Internet and intra-firm information sources were key to these firms. This supports the conclusion that regional spin-off/start-up firms surrounding the University of Waterloo did not channel regional technological triggers by the means of local network linkages (see, also, Xu, 2003), different from assumptions in the cluster literature (Porter, 1990). ${ }^{17}$

Overall, these results suggest that restructuring successes in the CTT region were primarily due to individual-firm competencies, rather than the consequence of collective action or local innovation networks.

\subsection{Institutional Linkages and Support}

In the previous section, we observed that the firms interviewed did not have strong produceruser linkages within the CTT region. Firms in the region often used non-local customers as their key source for new ideas, while the process of solving implementation challenges was typically resolved within the firms and/or with reliance on peer-Internet communities. In this section, we extend this discussion by investigating the role of institutional linkages and support in innovation, focusing on the role of public R\&D laboratories/universities, business organizations, government bodies, and peers/regional skill-sets. As suggested in the literature, such linkages can be important as they create

\footnotetext{
${ }^{17}$ There were some exceptions, however, which indicated that different practices also existed. Interestingly, firms that recognized the importance of being physically close to others mentioned this in the context of dealing with or visiting foreign customers.
} 
favorable conditions for economic interaction, establish a trust basis, and enable continuous reproduction (Hodgson, 1988; Gertler, 2004).

(i) Public R\&D laboratory/university linkages. Collaborations with public R\&D laboratories and universities were generally not very common among the sample population: over $70 \%$ of the firms (13) did not engage in university research opportunities, and about $85 \%$ (15) did not utilize public R\&D laboratories. The few firms that had collaborative relationships with public research laboratories typically also had relationships with universities. University research generally involves a mix of scientific discovery, testing, and prototype development, whereas public R\&D laboratories tend to be more focused on mission-oriented assignments, standard-setting responsibilities, and scientific projects that require capital and human resources beyond those available to private sector research organizations (Leslie, 1993). Based on this multitude of functions, the motivation of firms to collaborate with either of these organizations seems to depend on the project at hand, and is driven by the needs of the R\&D strategy (Bercovitz and Feldman, 2007). Despite different motivations to collaborate with universities and public R\&D laboratories, we found that many of the firms did not draw specific knowledge from their interaction with the University of Waterloo. Given the context of our research, as well as media reports about the region, this was unexpected. Such linkages did not establish a coherent basis for the development of networks or clusters in the sense of Bathelt and Boggs (2003).

One respondent from a manufacturer of high-precision measuring devices who used both university and public R\&D laboratories stated: "They are the ones who are exploring the frontiers of where our technology will be used in the medical field five or more years out ... The universities are mostly for monitoring rather than problem solving” (Interview 3). For this firm, public R\&D laboratories provided foresight into future possibilities. Parallel, the firm also tapped into a strong international network of research partners and established a European development facility as a center of excellence for electromagnetic applications. 
The three firms which indicated that they collaborated with public R\&D laboratories were all hardware producers. The innovation and product development processes of software firms aligned infrequently with the research conducted at universities, whereas hardware developers seemingly found collaborative projects more readily.

(ii) Business organization linkages. In terms of business organizations, Communitech was frequently mentioned as a contact partner by the interviewees, but only one third (6) utilized its service offerings. Communitech partners with public entities from all levels of government, business associations, educational institutions, and technology organizations to support the region's technology sector through various initiatives (Wahl, 2007). These initiatives include business and technology forums, seminars, conferences, and peer-to-peer events ranging from general business operations to specific networking events for executives. Many interviewees pointed out the importance of Communitech for the regional industry, even though relatively few seemed to be involved in intensive interaction and no one viewed it as decisive to innovation. The peer-to-peer events were found to be particularly useful as one of our interviewees emphasized:

"Software developers in the region use common tools, such as Java and Dot.Net. The software developer folks here get together with their peers at the Communitech groups and talk shop. That gets them excited about their chosen domains, and they come back here and apply it to the health care sector. We saw that with virtualization. We've tapped into the local community, sponsored internal forums based on that, and we have sites all over the world that are using virtualization technology" (Interview 1).

Another firm was less enthusiastic, rating Communitech "not critical, but of value" (Interview 6). The peer-to-peer sessions did not primarily have educational value to the participants, but helped to deepen social networks. One executive noted: "They are good at sponsoring meetings of best-practice leaders, and that's really important for keeping [our firm] really sharp" (Interview 3). Of the 6 firms 
who indicated that they made use of Communitech's services, half said that they used them for programmers to keep up with generic knowledge in the field, and half also indicated that this was a good resource to keep up-to-date with business practices; 4 firms further suggested that participation was valuable because it generated access to trends and gossip, especially related to human resources in the region. The peer-to-peer programs seemed valuable to firms to access generic knowledge, but domain-specific or specialized knowledge that is an essential input into innovation was not shared. ${ }^{18}$

In general, the firms in our sample population had weak linkages to local business organizations. CTT Inc. was not mentioned in this context. Although firms were aware of this organization, and highly valued the work of CTT Inc. in marketing the region, none of the interviewees deemed it important for their own business activities. One possible explanation for this might be that CTT Inc. is primarily concerned with attracting businesses and entrepreneurs to the region, and the development of private and public partnerships, which seemed less relevant for the IT firms examined in this study. ${ }^{19}$ Overall, these organizations did not stimulate innovation networks to support cluster-like developments in the sense of Cooke and Morgan (1998).

(iii) Government linkages. Local, provincial, or federal public business or economic development organizations were not mentioned at all by the interviewees, but, when asked about them, they were primarily acknowledged as instruments that ensured that locational attributes such as infrastructure or operational space were in place. Nevertheless, it was also pointed out that, even if such organizations did not directly impact the innovative capacity of local firms or explicitly stimulate

${ }^{18}$ Additional informal peer groups which exist outside of Communitech were not mentioned as being significant for innovation. The Accelerator Centre, which is an organization that was launched in 2006, related to Communitech to provide mentorship to new start-ups, was also not mentioned by our respondents.

${ }^{19}$ Our research also does not indicate that further informal networks such as "angle networks" or other organizations were of specific importance in innovation, even though we explicitly asked about such contacts. 
cluster development, they performed important functions, such as the provision of adequate immigration policies which allowed firms to attract international talent. At best, they might influence the innovative output of firms in the region in an indirect sense.

(iv) Peer linkages/regional skill-sets. Although the firms interviewed appeared relatively isolated in terms of inter-organizational linkages that provided significant input into the innovation process, the respondents had developed close peer relationships over the course of their university and professional lives. When asked to rate the role that peer contacts played in problem solving, all firms indicated that these relationships were not sources of ideas or knowledge regarding innovation; however, they also mentioned that they sometimes drew upon such contacts for problem-solving activities (Table 6). These were primarily social relationships and sources of gossip, specifically about staffing issues and the health of other firms in the region. Not surprisingly, such relational ties with peers tended to be trustful and allowed for a relatively open exchange of information - without requiring spatial proximity (Bathelt and Boggs, 2003).

All interviewees identified the skill-sets and knowledge of their employees as the single most important factor contributing to innovative success within their market. The ability of local firms to attract highly skilled personnel can thus be viewed as key to their continued success. In addition to a general set of programming skills, the IT firms interviewed also demanded a specific skill-set from their workers. The skills of university graduates, including some specialized knowledge and/or work experience, largely seemed to satisfy these entry-level requirements. Once working for a firm, employees were usually expected to engage in extensive on-the-job learning and training.

Overall, innovative inputs through collaborative research with the local universities were clearly less important than expected, but many interviewees mentioned two other specific facets by which the University of Waterloo, in particular, provided important linkages supportive to innovation: First, the university's progressive intellectual property policy was mentioned, even though only a few firms 
benefited from it directly when they started up their venture. Second, the reputable co-operative education program, which is currently the largest program of this nature in the world (Nelles et al., 2005), provided a steady influx of talent for the local firms on a contractual basis (Wahl, 2007; Bramwell and Wolfe, 2008). The University of Waterloo is a pioneer of this form of temporary student placement, and one of its main advantages, as pointed out by several respondents, is that it distributes student placement among local firms on a cyclical basis. Several respondents mentioned that the co-op program made it easier to carry out short-term projects that needed additional human resources, due to the flexible temporary workforce provided by the University of Waterloo. Overall though, the institutional basis to trigger cohesive regional innovation networks was not well developed in the CTT region.

\section{Conclusions: Individual vs. Collective Inputs for Innovation in the CTT Region}

In summary, our research offers some interesting insights into the social dynamics of innovation in a second-tier city-region in Canada. Although the CTT region is frequently portrayed as a dynamic technology region that draws from university-related start-up/spin-off processes, knowledge transfers, and corresponding regional networks in the IT field, our research illustrates a different picture of the development in this region. In contrast to what we expected, we did not find proof of strong valuechain-based or cross-sectoral networks and knowledge flows.

We set out with the assumption that university-related start-ups/spin-offs in the area of IT would be the most likely of ventures that should demonstrate evidence of strong horizontal and vertical relationships in innovation, leading to local buzz. However, the empirical results derived from our interviews showed that, first, there were fewer such start-ups/spin-offs than expected and, second, most of these firms operated in specific cross-regional networks along market and technology linkages that adhere to their particular technological expertise. Local linkages with customers and suppliers, and the 
existence of regional industry networks, such as those described in conventional cluster approaches, were quite limited in their extent, or absent altogether. Firms seemed to construct relevant relationships frequently via Internet communication and non-local collaborations that followed from it.

Although the IT sector may be somewhat specific in terms of its ability to create international networks, it does not possess fundamentally different linkage patterns than other new technologies. In particular, we expected university start-up/spin-off firms to display a somewhat stronger regional orientation, especially in their early stages. This was, however, not the case. We found three reasons that help to explain this: First, it seemed that firms in the area of specialized software solutions were able to establish a broader extra-regional customer base more quickly and easily than firms in other industries. Second, regional firms were extremely diversified, limiting the opportunities for local network creation in a mid-sized metropolitan region. Third, acquisitions by larger entities that took place within the region served to provide access to wider extra-regional corporate networks, and thus boosted market legitimacy for the respective units. Overall, we found that these firms created limited specialized local buzz in innovation. With respect to our conceptual expectations regarding the conditions for regional clustering and innovation, we found that most firms were stand-alone units in the regional economy with strong international customer linkages, particularly to the US. They had little ongoing research activities with R\&D laboratories and universities. Regional industry organizations also played a limited role in stimulating innovation. It is unlikely that such limited innovation linkages could spur the development of a specialized industry agglomeration as described in the cluster literature.

Despite the lack of strong regional relationships, IT spin-off/start-up firms appeared to be clearly embedded in the community structure. The University of Waterloo provided important skill flows to the regional firms in the form of qualified graduates, but these were generic skill flows that did not directly strengthen innovative capabilities. As Bill Gates, Microsoft Corp., emphasized during a visit to the region: "Most years, we hire more students out of Waterloo than any university in the world, 
typically 50 or even more" (CTV.ca, 2005). In contrast to these labor market effects, our study indicated that less specific knowledge is being transferred to the region by entrepreneurial faculty members and graduates than we would have expected. Over time, existing university spin-offs/startups seemingly entered a stage of incremental innovation, with few strong R\&D relationships to the university (or the region) persisting.

Although our empirical work is strictly related to the CTT case, it is tempting to draw some wider conclusions regarding university spin-off processes and regional technology transfer effects (Bathelt et al., 2010). Considering that the University of Waterloo is often portrayed as one of the key examples of strong technology transfer with its surrounding economy, we might have to lower our expectations regarding such exchange processes. There are surprisingly few concrete examples of strong technology linkages between universities and their regional economy, and even cases, such as Stanford University, MIT, and the University of Cambridge, are inconclusive. It might be more precise to conclude that it is primarily weak ties and generic knowledge that hold together the fabric of innovation in a region. The role of local universities as a source of spin-off/start-up firms or as a partner in leading-edge research appears sometimes over-stated, which does not mean, of course, that local universities are not significant places of knowledge generation.

This is a different story of the CTT region and the University of Waterloo from that portrayed in the media and transpired, in part, through academic publications. In the CTT region, successful restructuring and modernization in the past was primarily a result of individual strengths, shared generic knowledge assets, and a strong sense of community in marketing the region's attributes, rather than the effect of collective innovation or networking. Although this fragmented regional economy may experience strong growth in some future periods based on diversification advantages, it may under-perform due to a lack of economic cohesion, and little collective synergies at other times. This indicates that the CTT region may not have quite entered the "post-industrial" age, as a recent newspaper report suggests (Perry 2009). 


\section{Acknowledgements}

Parts of this paper were presented in 2008 at the annual meeting of the Association of American Geographers in Boston and the conference of the Canadian Innovation Systems Research Network (ISRN) in Montreal. We very much appreciate the comments made by many individuals during these conferences, especially Jürgen Essletzbichler, Meric Gertler, Jill Grant, Adam Holbrook, Nicole Kogler, Réjean Landry, Henrik Mattson, and David Wolfe. Furthermore, we would like to thank Mark Lorenzen and four anonymous referees for supportive suggestions on how to sharpen our argument. 


\section{References}

Amin, A. and Cohendet, P. (1999): Learning and adaptation in decentralized business networks. Environment and Planning D: Society and Space 17: 87-104.

Bathelt, H. (1991): Employment changes and input-output linkages in key technology industries: a comparative analysis. Regional Studies 25: 31-43.

Bathelt, H. and Boggs, J. S. (2003): Towards a reconceptualization of regional development paths: is Leipzig's media cluster a continuation of or a rupture with the past? Economic Geography 79: 265-293.

Bathelt, H. and Hecht, A. (1990): Key technology industries in the Waterloo region: Canada's Technology Triangle (CTT). Canadian Geographer 34: 225-234.

Bathelt, H., Kogler, D. F. and Munro, A. K. (2010): A knowledge-based typology of university spinoffs in the context of regional economic development. Technovation 30: 519-532.

Bathelt, H., Malmberg, A. and Maskell, P. (2004): Clusters and knowledge: local buzz, global pipelines and the process of knowledge creation. Progress in Human Geography 28: 31-56.

Bercovitz, J. E. L. and Feldman, M. P. (2007): Fishing upstream: firm innovation strategy and university research alliances. Research Policy 36: 930-948.

Boschma, R. A. (2005): Proximity and innovation: a critical assessment. Regional Studies 39: 61-74.

Brady, D. (2004): RIM's Lazaridis. Interview with Mike Lazaridis. Business Week Online (URL: http://www.businessweek.com/magazine/content/04_16/b3879097.htm, date accessed April 27, 2008).

Bramwell, A., Nelles, J. and Wolfe, D. A. (2008): Knowledge, innovation and institutions: global and local dimensions of the ICT cluster in Waterloo, Canada. Regional Studies 42: 101-116.

Bramwell, A. and Wolfe, D. A. (2008): Universities and regional economic development: the entrepreneurial University of Waterloo. Research Policy 37 (8): 1175-1187.

Chevreau, J. (1988): Caution: future under construction. Challenges (March): 14-17.

Cities of Cambridge, Waterloo, Kitchener and Guelph (1988): Canada's Technology Triangle: Economic Profile. Brochure. Kitchener.

Colapinto, C. (2007): A way to foster innovation: a venture capital district from Silicon Valley and Route 128 to Waterloo Region. International Review of Economics 54: 319-343.

Communitech (2006): State of the Industry - Technology in the Waterloo Region: Report 2006. Waterloo. 
Conestoga College (2003): The Economic and Social Value of Conestoga College. Brochure. Kitchener.

Cooke, P. and Morgan, K. (1998): The Associational Economy. Oxford: Oxford University Press.

Cooper, A. C. (1971): Spin-offs and technical entrepreneurship. IEEE Transactions on Engineering Management 18: 2-6.

CTV.ca (2005): Bill Gates draws a crowd at Waterloo University. Toronto (URL:

http://www.ctv.ca/servlet/ArticleNews/story/CTVNews/20051013/billgates_waterloo_2005101 3/20051013?hub=Canada, date accessed April 27, 2008).

de Jong, M. W. (1987): New Economic Activities and Regional Dynamics. Nederlandse Geografische Studies - No. 38. Amsterdam.

Etzkowitz, H., Webster, A., Gebhardt, C. and Cantisano Terra, B. R. (2000): The future of the university and the university of the future: evolution of ivory tower to entrepreneurial paradigm. Research Policy 29: 313-330.

Feldman, M. and Francis, J. (2004): Home grown solutions: fostering cluster formation through entrepreneurship. Economic Development Quarterly 18: 127-137.

Feldman, M., Francis, J. and Bercovitz, J. (2005): Creating a cluster while building a firm: entrepreneurs and the formation of industrial clusters. Regional Studies 39: 129-141

Gertler, M. S. (2004): Manufacturing Culture: The Institutional Geography of Industrial Practice. Oxford, New York: Oxford University Press.

Gordon, I. R. and McCann, P. (2000): Industrial clusters: complexes, agglomeration and/or social networks. Urban Studies 37: 513-532.

Hannan, M. T. and Freeman, J. (1993): Organizational Ecology. Cambridge (MA), London: Harvard University Press.

Hayter, R. (1997): The Dynamics of Industrial Location: The Factory, the Firm and the Production System. Chicester, New York: Wiley.

Henn, S. (2006): Regionale Cluster in der Nanotechnologie: Entstehung, Eigenschaften, Handlungsempfehlungen (Regional Clusters of Nanotechnology: Genesis, Characteristics, Policy Implications). Frankfurt/Main: Peter Lang.

Hodgson, G. M. (1988). Economics and Institutions: A Manifesto for a Modern Institutional Economics. Cambridge: Polity Press.

Holbrook, J. A. and Wolfe, D. A. (2005): The innovation systems research network: a Canadian experiment in knowledge management. Science and Public Policy 2 (1): 109-118. 
Jeppesen, L. B. and Frederiksen, L. (2006): Why do users contribute to firm-hosted user communities? The case of computer-controlled music instruments. Organization Science 17 (1): 45-63.

Klepper, S. (1996): Entry, exit, growth, and innovation over the product life cycle. American Economic Review 86 (3): 562-583.

Klepper, S. and Sleeper, S. (2005): Entry by spinoffs. Management Science 51 (8): 1291-1306.

Leslie, S. W. (1993): The Cold War and American Science: The Military-Industrial-Academic Complex at MIT and Stanford. New York: Columbia University Press.

Livingston, J. (2007): Founders at Work: Stories of Startups’ Early Days. NewYork: Apress.

Lockett, A., Wright, M. and Franklin, S. (2003): Technology transfer and universities' spin-out strategies. Small Business Economics 20: 185-201.

Lundvall, B.-Å. (1988): Innovation as an interactive process: from producer-user interaction to the national system of innovation. In: Dosi, G., Freeman, C., Nelson, R. R., Silverberg, G. and Soete, L. L. G. (eds.): Technical Change and Economic Theory. London, New York: Pinter, pp. 349-369.

Lundvall, B.-Å. and Johnson, B. (1994): The learning economy. Journal of Industry Studies 1: 23-42.

MacKinnon, D., Cumbers, A., Pike, A., Birch, K. and McMaster, R. (2009): Evolution in economic geography: institutions, political economy, and adaptation. Economic Geography 85: 129-150.

Malecki, E. J. (1991): Technology and Economic Development: The Dynamics of Local, Regional, and National Change. Burnt Mill: Longman.

Malmberg, A. and Maskell, P. (2002): The elusive concept of localization economies: towards a knowledge-based theory of spatial clustering. Environment and Planning A 34: 429-449.

Maskell, P. and Lorenzen, M. (2004): The cluster as market organisation. Urban Studies 41: 991-1009.

Morgan, K. (2004): The exaggerated death of geography: learning, proximity and territorial innovation systems. Journal of Economic Geography 4: 3-21.

Nelles, J., Bramwell, A. and Wolfe, D. A. (2005): History, culture, and path dependency: origins of the Waterloo ICT cluster. In: Wolfe, D. A. and Lucas, M. (eds.): Global Networks and Local Linkages. Montreal, Kingston: McGill-Queen's University Press, pp. 227-252.

Nicolaou, N. and Birley, S. (2003): Academic networks in a trichotomous categorisation of university spinouts. Journal of Business Venturing 18 (3): 333-359.

Niosi, J. (2000): Canada’s National System of Innovation. Montreal, Kingston: McGill-Queen's University Press.

Niosi, J. and Banik, M. (2005): The evolution and performance of biotechnology regional systems of innovation. Cambridge Journal of Economics 29: 343-357. 
Nooteboom, B. (2000): Learning and Innovation in Organizations and Economies. Oxford: Oxford University Press.

Oinas, P. and Malecki, E. J. (1999): Spatial innovation systems. In: Malecki, E. J. and Oinas, P. (eds.): Making Connections: Technological Learning and Regional Economic Change. Aldershot: Ashgate, pp. 7-33.

Owen-Smith, J. and Powell, W. W. (2004): Knowledge networks as channels and conduits: the effects of spillovers in the Boston biotechnology community. Organization Science 15: 2-21.

Parker, P. (2001): Local-global partnerships for high-tech development: integrating top-down and bottom-up models. Economic Development Quarterly 15: 149-167.

Perry, A. (2009): Meet our post-industrial Waterloo. Toronto Star, March 21, p. B2.

Pinch, S., Henry, N., Jenkins, M. and Tallmann, S. (2003): From 'industrial districts' to 'knowledge clusters': a model of knowledge dissemination and competitive advantage in industrial agglomerations. Journal of Economic Geography 3: 373-388.

Pirnay, F., Surlemont, B. and Nlemvo, F. (2003): Towards a typology of university spin-offs. Small Business Economics 21: 355-369.

Porter, M. E. (1990): The Competitive Advantage of Nations. New York: Free Press.

Porter, M. E. (2000): Locations, clusters, and company strategy. In: Clark, G. L., Feldman, M. P. and Gertler, M. S. (eds.): The Oxford Handbook of Economic Geography. Oxford: Oxford University Press, pp. 253-274.

Preissl, B. and Solimene, L. (2003): The Dynamics of Clusters and Innovation. Heidelberg, New York: Physica.

PricewaterhouseCoopers (2001a): Waterloo Region/Canada's Technology Triangle 2001: Techmap. Waterloo.

PricewaterhouseCoopers (2001b): University of Waterloo: Regional Economics Benefits Study. Waterloo.

Roberts, E. B. (1968): Entrepreneurship and technology: a basic study of innovators; how to keep and capitalize on their talents. Research Management 11: 249-266.

Rutherford, T. D. (1996): The local solution? The Schumpeterian workfare state, labour market governance and local boards for training in Kitchener, Ontario. Regional Studies 30: 413-427.

Rutherford, T. and Holmes, J. (2007): Entrepreneurship, knowledge and learning in the formation and evolution of industrial clusters: the case of the Windsor, Ontario tool, die and mould cluster. International Journal of Entrepreneurship and Innovation Management 7: 320-344. 
Rutherford, T. and Holmes, J. (2008): Engineering networks: university-industry networks in southern Ontario automotive industry clusters. Cambridge Journal of Regions, Economy and Society 1: 247-264.

Saxenian, A. (1985): The genesis of Silicon Valley. In: Hall, P. and Markusen, A. R. (eds.): Silicon Landscapes. Boston: Allen and Unwin, pp. 20-34.

Scott, A. J. (2006): Spatial and organizational patterns of labor markets in industrial clusters: the case of Hollywood. In: Asheim, B., Cooke, P. and Martin, R. (eds.): Clusters and Regional Development: Critical Reflections and Explorations. London, New York: Routledge, pp. 236254.

Setterfield, M. (1993): A model of institutional hysteresis. Journal of Economic Issues 27: 755-774.

Spencer, G. M., Vinodrai, T., Gertler, M. S. and Wolfe, D. A. (2010): Do clusters make a difference? Defining and assessing their economic performance. Regional Studies 44: 697-715.

Statistics Canada (2001a): Census of Canada 2001: Profile Series, Cumulative Files. Catalogue No. 95F0495XCB01001 and 95F0495XCB01004. Ottawa: Statistics Canada.

Statistics Canada (2001b): Industry - 1997 North American Industry Classification System, Class of Worker and Sex for Labour Force 15 Years and Over. Catalogue No. 97F0012XCB01009. Ottawa: Statistics Canada.

Statistics Canada (2006a): Census of Canada 2006: Profile Series, Cumulative Files. Catalogue No. 94-581-XCB2006001 and 94-581-XCB2006004. Ottawa: Statistics Canada.

Statistics Canada (2006b): Industry - 2002 North American Industry Classification System, Class of Worker and Sex for Labour Force 15 Years and Over. Catalogue No. 97-559-XCB2006009. Ottawa: Statistics Canada.

Statistics Canada (2006c): Canadian Business Patterns, 1998-2005. Catalogue No. 61F0040XCB. Ottawa: Statistics Canada.

Storper, M. and Venables, A. J. (2004): Buzz: face-to-face contact and the urban economy. Journal of Economic Geography 4: 351-370.

Storper, M. and Walker, R. (1989): The Capitalist Imperative: Territory, Technology, and Industrial Growth. New York, Oxford: Basil Blackwell.

Trippl, M., Tödtling, F. and Lengauer, L. (2009): Knowledge sourcing beyond buzz and pipelines: evidence from the Vienna software sector. Economic Geography 85: 443-462.

Visser, E.-J. and Atzema, O. (2008): With or without clusters: facilitating innovation through a differentiated and combined network approach. European Planning Studies 16: 1169-1188. 
Vohora, A., Wright, M. and Lockett A. (2004): Critical junctures in the development of university high-tech spinout companies. Research Policy 33: 147-175.

Wahl, A. (2007): Innovation station. Canadian Business, October 8.

Wolfe, D. A. and Gertler, M. S. (2004): Clusters from the inside and out: local dynamics and global linkages. Urban Studies 41: 1071-1093.

Wright, M., Birley, S. and Mosey, S. (2004): Entrepreneurship and university technology transfer. Journal of Technology Transfer 29: 235-246.

Xu, S. X. (2003): Knowledge Transfer, Inter-Firm Networking and Collective Learning in High Technology Cluster Evolution: A Network Analysis of Canada's Technology Triangle. Master Thesis. Waterloo: University of Waterloo. 
Table 1. Socio-economic indicators of the Kitchener CMA and Guelph CA in relation to the Toronto CMA, Ontario and Canada, 2001 - 2006 (Sources: Statistics Canada, 2001a; 2006a)

\begin{tabular}{lrrrrr}
\hline Socio-economic indicators & Canada & Ontario & $\begin{array}{r}\text { Toronto } \\
\text { CMA }^{1)}\end{array}$ & $\begin{array}{r}\text { Kitchener } \\
\text { CMA }^{1)}\end{array}$ & $\begin{array}{r}\text { Guelph } \\
\text { CA }^{2)}\end{array}$ \\
\hline $\begin{array}{l}\text { Population growth, } \\
\text { 2001 - 2006 }\end{array}$ & $5.4 \%$ & $6.6 \%$ & $9.2 \%$ & $8.9 \%$ & $8.2 \%$ \\
Unemployment rate, 2006 & $6.6 \%$ & $6.4 \%$ & $6.7 \%$ & $5.6 \%$ & $5.1 \%$ \\
$\begin{array}{l}\text { Average household income, } \\
\text { CAD 2005 }\end{array}$ & 69,550 & 77,970 & 87,820 & 78,220 & 77,920 \\
$\begin{array}{l}\text { Employment growth, } \\
\text { 2001 - 2006 }\end{array}$ & $8.2 \%$ & $8.0 \%$ & $9.4 \%$ & $10.7 \%$ & $9.7 \%$ \\
- Construction & $21.6 \%$ & $15.8 \%$ & $19.7 \%$ & $19.7 \%$ & $14.4 \%$ \\
- Manufacturing & $-7.7 \%$ & $-8.6 \%$ & $-6.2 \%$ & $-3.5 \%$ & $2.9 \%$ \\
- Finance and insurance & $8.4 \%$ & $8.1 \%$ & $9.3 \%$ & $14.3 \%$ & $-0.4 \%$ \\
- Professional, scientific and & $14.3 \%$ & $9.9 \%$ & $8.5 \%$ & $23.9 \%$ & $19.0 \%$ \\
$\quad \begin{array}{l}\text { technical services } \\
\text { - Administrative and }\end{array}$ & $19.3 \%$ & $22.2 \%$ & $19.9 \%$ & $36.0 \%$ & $42.3 \%$ \\
$\quad$ support, and other services & & & & & \\
- Educational services & $12.7 \%$ & $16.8 \%$ & $20.1 \%$ & $20.3 \%$ & $8.9 \%$ \\
\hline
\end{tabular}

Notes: ${ }^{1)} \mathrm{CMA}=$ census metropolitan area; ${ }^{2)} \mathrm{CA}=$ census agglomeration 
Table 2. Employment and establishments in the Kitchener and Guelph metropolitan areas by selected industry groups, 2001 - 2006 (Sources: Statistics Canada, 2001b; 2006b; 2006c)

\begin{tabular}{|c|c|c|c|c|c|c|}
\hline \multirow[t]{2}{*}{ NAICS ${ }^{1)}$ industry groups } & \multicolumn{3}{|c|}{ Employees } & \multicolumn{3}{|c|}{ Establishments } \\
\hline & $\begin{array}{r}\text { number } \\
2001\end{array}$ & $\begin{array}{r}\text { number } \\
2006\end{array}$ & $\%$ change & $\begin{array}{r}\text { number } \\
2001\end{array}$ & $\begin{array}{r}\text { number } \\
2006\end{array}$ & $\%$ change \\
\hline $31-33$ Manufacturing & 76,500 & 74,915 & $-2.1 \%$ & 1,556 & 1,477 & $-5.1 \%$ \\
\hline 313 Textile mills & 900 & 425 & $-52.8 \%$ & 18 & 11 & $-38.9 \%$ \\
\hline 315 Clothing manufacturing & 2,275 & 775 & $-65.9 \%$ & 30 & 22 & $-26.7 \%$ \\
\hline $\begin{array}{l}316 \text { Leather and allied product } \\
\text { manufacturing }\end{array}$ & 290 & 120 & $-58.6 \%$ & 7 & 9 & $28.6 \%$ \\
\hline 325 Chemical manufacturing & 2,405 & 1,960 & $-18.5 \%$ & 50 & 44 & $-12.0 \%$ \\
\hline $\begin{array}{l}326 \text { Plastics and rubber products } \\
\text { manufacturing }\end{array}$ & 5,255 & 6,445 & $22.6 \%$ & 86 & 83 & $-3.5 \%$ \\
\hline $\begin{array}{l}334 \text { Computer and electronic } \\
\text { product manufacturing }\end{array}$ & 4,515 & 5,460 & $20.9 \%$ & 70 & 66 & $-5.7 \%$ \\
\hline $\begin{array}{l}335 \text { Electrical equipment, appliance } \\
\text { and component manufacturing }\end{array}$ & 4,630 & 3,700 & $-20.1 \%$ & 55 & 49 & $-10.9 \%$ \\
\hline 51 Information and cultural $i$ & 5,925 & 6,430 & $8.5 \%$ & 169 & 149 & $-11.8 \%$ \\
\hline 52 Finance and insurance & 14,875 & 16,640 & $11.9 \%$ & 589 & 724 & $22.9 \%$ \\
\hline 53 Real estate and rental and leasing & 4,105 & 5,135 & $25.1 \%$ & 609 & 665 & $9.2 \%$ \\
\hline $\begin{array}{l}54 \text { Professional, scientific and } \\
\text { technical services }\end{array}$ & 16,425 & 20,150 & $22.7 \%$ & 1,755 & 1,924 & $9.6 \%$ \\
\hline $\begin{array}{l}55 \text { Management of companies and } \\
\text { enterprises }\end{array}$ & 1,125 & 390 & $-65.3 \%$ & 278 & 188 & $-32.4 \%$ \\
\hline $\begin{array}{l}56 \text { Administrative and support, waste } \\
\text { management/remediation services }\end{array}$ & 9,930 & 13,602 & $37.2 \%$ & 708 & 803 & $13.4 \%$ \\
\hline Total & 149,155 & 156,147 & $4.7 \%$ & 5,980 & 6,214 & $3.9 \%$ \\
\hline
\end{tabular}

Notes: ${ }^{1)}$ NAICS $=$ North American Industry Classification System 
Table 3. University-related spin-off/start-up firms in the Kitchener/Guelph metropolitan areas

\begin{tabular}{|c|c|c|c|c|}
\hline Firm category & $\begin{array}{l}\text { University- } \\
\text { related start- } \\
\text { ups }^{1)} \text { (number) }\end{array}$ & $\begin{array}{l}\text { University of } \\
\text { Waterloo spin- } \\
\text { offs }^{2)} \text { (number) }\end{array}$ & $\begin{array}{l}\text { University of } \\
\text { Guelph spin- } \\
\text { offs }^{2)} \text { (number) }\end{array}$ & $\begin{array}{c}\text { Total } \\
\text { (number) }\end{array}$ \\
\hline \multicolumn{5}{|c|}{ - A. Sectoral split-up - } \\
\hline - All firms & 227 & 47 & 14 & $288(100.0 \%)$ \\
\hline - IT firms & 94 & 24 & 1 & $119(41.3 \%)$ \\
\hline $\begin{array}{l}\text { - Engineering } \\
\text { firms }\end{array}$ & 69 & 13 & 1 & $83(28.8 \%)$ \\
\hline - Other firms & 64 & 10 & 12 & $86(29.9 \%)$ \\
\hline \multicolumn{5}{|c|}{ - B. IT firm status/trajectory - } \\
\hline - IT firms & 94 & 24 & 1 & $119(100.0 \%)$ \\
\hline $\begin{array}{l}\text { - IT firms } \\
\text { confirmed } \\
\text { closed }\end{array}$ & 14 & 3 & 0 & $17(14.3 \%)$ \\
\hline $\begin{array}{l}\text { - IT firms not } \\
\text { found }\end{array}$ & 16 & 0 & 0 & $16(13.4 \%)$ \\
\hline $\begin{array}{l}\text { - IT firms not in } \\
\text { region }\end{array}$ & 30 & 6 & 0 & $36(30.3 \%)$ \\
\hline $\begin{array}{l}\text { - IT firms } \\
\text { acquired by } \\
\text { other IT firms }\end{array}$ & 6 & 2 & 0 & $8(\quad 6.7 \%)$ \\
\hline $\begin{array}{l}\text { - Relevant IT } \\
\text { firm population }\end{array}$ & 28 & 13 & 1 & $42(35.3 \%)$ \\
\hline \multicolumn{5}{|c|}{ - C. Sample statistics - } \\
\hline $\begin{array}{l}\text { Relevant } \\
\text { population }(\mathrm{N})\end{array}$ & 28 & 13 & 1 & $42(100.0 \%)$ \\
\hline Contacted firms & 24 & 8 & 0 & $32(76.2 \%)$ \\
\hline Rejections & 11 & 3 & 0 & $14(33.3 \%)$ \\
\hline Interviews (n) & 13 & 5 & 0 & $18(42.9 \%)$ \\
\hline
\end{tabular}

Notes: ${ }^{1)}$ University-related start-ups were identified from the PricewaterhouseCoopers (2001a) techmap. ${ }^{2)}$ Lists of university spin-offs were provided by the universities. 
Table 4. Economic indicators of the sampled IT-related University of Waterloo spin-off/start-up firms, 2008

\begin{tabular}{|c|c|c|c|c|c|c|c|c|c|c|c|c|}
\hline \multirow{2}{*}{$\begin{array}{l}\text { Inter- } \\
\text { view } \\
\text { no. }\end{array}$} & \multirow{2}{*}{$\begin{array}{l}\text { Date } \\
\text { estab- } \\
\text { lished }\end{array}$} & \multirow{2}{*}{$\begin{array}{l}\text { Owner- } \\
\text { ship }\end{array}$} & \multirow{2}{*}{$\begin{array}{l}\text { Product/ } \\
\text { service } \\
\text { type }\end{array}$} & \multirow{2}{*}{$\begin{array}{l}\text { Number of } \\
\text { regional } \\
\text { employees }\end{array}$} & \multirow{2}{*}{$\begin{array}{l}\text { Share of } \\
\text { local } \\
\text { supplies }\end{array}$} & \multicolumn{4}{|c|}{ Share of sales } & \multirow{2}{*}{$\begin{array}{l}\text { University } \\
\text { sponsorship in } \\
\text { start-up phase }\end{array}$} & \multirow{2}{*}{$\begin{array}{l}\text { Form of university } \\
\text { involvement }\end{array}$} & \multirow{2}{*}{$\begin{array}{l}\text { Existing uni- } \\
\text { versity colla- } \\
\text { borations }\end{array}$} \\
\hline & & & & & & $\begin{array}{l}\text { Local } \\
\text { sales }\end{array}$ & $\begin{array}{l}\text { Other } \\
\text { Canad- } \\
\text { ian sales } \\
\end{array}$ & $\begin{array}{l}\text { US } \\
\text { sales }\end{array}$ & $\begin{array}{l}\text { Other in- } \\
\text { ternational } \\
\text { sales }\end{array}$ & & & \\
\hline 1 & 1991 & Public & Software & 250 & $5 \%$ & $\mathrm{n} / \mathrm{a}$ & $\mathrm{n} / \mathrm{a}$ & $\mathrm{n} / \mathrm{a}$ & $\mathrm{n} / \mathrm{a}$ & Unsponsored & No direct involvement & Yes \\
\hline 2 & 1977 & Public & Software & 84 & $<1 \%$ & $1 \%$ & $1 \%$ & $60 \%$ & $40 \%$ & Unsponsored & No direct involvement & No \\
\hline 3 & 1981 & Private & $\begin{array}{l}\text { Instrum- } \\
\text { ents }\end{array}$ & 145 & $20 \%$ & $1 \%$ & $13 \%$ & $37 \%$ & $48 \%$ & Sponsored & $\begin{array}{l}\text { Founder was staff; IP } \\
\text { from custom contract }\end{array}$ & Yes \\
\hline 4 & 1991 & Public & Software & 9 & $<1 \%$ & $\mathrm{n} / \mathrm{a}$ & $\mathrm{n} / \mathrm{a}$ & $\mathrm{n} / \mathrm{a}$ & $\mathrm{n} / \mathrm{a}$ & Sponsored & $\begin{array}{l}\text { Initial product was spun- } \\
\text { out from another firm }\end{array}$ & No \\
\hline 5 & 1997 & Private & Software & 5 & $\mathrm{n} / \mathrm{a}$ & $\mathrm{n} / \mathrm{a}$ & $\mathrm{n} / \mathrm{a}$ & $\mathrm{n} / \mathrm{a}$ & $\mathrm{n} / \mathrm{a}$ & Unsponsored & $\begin{array}{l}\text { Founders met during co- } \\
\text { op term }\end{array}$ & No \\
\hline 6 & 1984 & Private & Software & 65 & $<1 \%$ & $1 \%$ & $9 \%$ & $40 \%$ & $50 \%$ & Sponsored & $\begin{array}{l}\text { Founder's undergrad- } \\
\text { uate project was basis } \\
\text { for firm }\end{array}$ & No \\
\hline 7 & 1991 & Public & Software & 12 & $<1 \%$ & $2 \%$ & $13 \%$ & $60 \%$ & $25 \%$ & Unsponsored & $\begin{array}{l}\text { Founder was staff and } \\
\text { bought IP }\end{array}$ & No \\
\hline 8 & 1984 & Private & Software & 6 & $10 \%$ & $5 \%$ & $85 \%$ & $5 \%$ & $5 \%$ & Unsponsored & $\begin{array}{l}\text { Founder was staff and } \\
\text { bought IP }\end{array}$ & No \\
\hline 9 & 1989 & Public & Software & 400 & $<1 \%$ & $0 \%$ & $3 \%$ & $45 \%$ & $52 \%$ & Sponsored & $\begin{array}{l}\text { Initial project was a uni- } \\
\text { versity-industry project }\end{array}$ & Yes \\
\hline 10 & 1976 & Private & Software & 5 & $<1 \%$ & $0 \%$ & $10 \%$ & $70 \%$ & $20 \%$ & Sponsored & $\begin{array}{l}\text { Founder was university } \\
\text { researcher }\end{array}$ & No \\
\hline 11 & 1976 & Private & Consulting & 450 & $<1 \%$ & $0 \%$ & $15 \%$ & $25 \%$ & $60 \%$ & Unsponsored & $\begin{array}{l}\text { Founders met at the } \\
\text { university }\end{array}$ & No \\
\hline 12 & 1988 & Private & Software & 150 & $<1 \%$ & $0 \%$ & $6 \%$ & $54 \%$ & $40 \%$ & Sponsored & $\begin{array}{l}\text { Main product was a uni- } \\
\text { versity research project }\end{array}$ & Yes \\
\hline 13 & 1980 & Public & $\begin{array}{l}\text { Semi- } \\
\text { conductors }\end{array}$ & 255 & $10 \%$ & $1 \%$ & $3 \%$ & $30 \%$ & $66 \%$ & Sponsored & Founder was a professor & Yes \\
\hline 14 & 1984 & Public & $\begin{array}{l}\text { Comm- } \\
\text { unication }\end{array}$ & 5200 & $<1 \%$ & $0 \%$ & $7 \%$ & $60 \%$ & $33 \%$ & Unsponsored & No direct involvement & Yes \\
\hline 15 & 1988 & Public & $\begin{array}{l}\text { Engineer- } \\
\text { ing }\end{array}$ & 3 & $100 \%$ & $98 \%$ & $1 \%$ & $0 \%$ & $1 \%$ & Unsponsored & No direct involvement & No \\
\hline 16 & 1998 & Public & $\begin{array}{l}\text { Semi- } \\
\text { conductors }\end{array}$ & 45 & $<1 \%$ & $0 \%$ & $0 \%$ & $0 \%$ & $100 \%$ & Unsponsored & No direct involvement & No \\
\hline 17 & 2004 & Private & Software & 39 & $<1 \%$ & $0 \%$ & $50 \%$ & $20 \%$ & $30 \%$ & Sponsored & $\begin{array}{l}\text { Main product was a uni- } \\
\text { versity research project }\end{array}$ & No \\
\hline 18 & 2000 & Private & Software & 20 & $10 \%$ & $1 \%$ & $20 \%$ & $70 \%$ & $10 \%$ & Unsponsored & $\begin{array}{l}\text { No direct involvement; } \\
\text { university an early client }\end{array}$ & No \\
\hline
\end{tabular}


Table 5. Importance of suppliers and customers in innovation for IT-related University of Waterloo spin-off/start-up firms, 2008

\begin{tabular}{lllllrr}
\hline Importance of suppliers and consumers in innovation & \multicolumn{5}{c}{ Number of responses ${ }^{1)}$ with the rating } \\
& 1 & 2 & 3 & 4 & 5 \\
\hline Suppliers $(\mathrm{n}=15)$ & 5 & 4 & 3 & 1 & 2 \\
Customers $(\mathrm{n}=15)$ & 0 & 0 & 3 & 4 & 8 \\
\hline
\end{tabular}

Notes: ${ }^{1)}$ Firms were asked to rate the importance of suppliers and customers in innovation processes on a scale from " $1 "=$ unimportant to " $5 "=$ critical. 
Table 6. Information sources in product design and problem solving for IT-related University of Waterloo spin-off/start-up firms, 2008

\begin{tabular}{lcr}
\hline $\begin{array}{l}\text { Information sources in problem solving/ } \\
\text { market development/product design }\end{array}$ & \multicolumn{2}{c}{$\begin{array}{c}\text { Responses }{ }^{1)} \text { of IT-related University of } \\
\text { Waterloo spin-offs/start-ups }\end{array}$} \\
\hline Internet as a source for innovation & Number (n = 18) & Share \\
$\quad$ - Of these: Internet is a key source & $96.7 \%$ \\
Peers (technology issues) & 1 & $50.0 \%$ \\
Peers (business related) & 3 & $5.6 \%$ \\
Public R\&D Labs & - & $16.7 \%$ \\
Consultants & 3 & $16.7 \%$ \\
Intra-firm sources & 6 & $33.3 \%$ \\
- Of these: other corporate sites & 3 & $16.7 \%$ \\
Universities & 4 & $22.2 \%$ \\
Customers and suppliers & 5 & $27.8 \%$ \\
\hline
\end{tabular}

Notes: ${ }^{1)}$ Firms were asked who they turn to for help to solve a problem related to product design, production, or market development. 